\title{
An Analysis of the Relationship between Crude Oil Prices, Current Account Deficit and Exchange Rates: Turkish Experiment
}

\author{
Çağatay Başarır ${ }^{1}$ \& Mehmet Emin Erçakar ${ }^{2}$ \\ ${ }^{1}$ Faculty of Application Sciences, Bandirma Onyedi Eylül University, Bandirma, Turkey \\ ${ }^{2}$ Faculty of Economics and Admisinistrative Sciences, Bandirma Onyedi Eylül University, Bandirma, Turkey \\ Correspondence: Çağatay Başarır, Bandirma Onyedi Eylül University, Faculty of Application Sciences, \\ Bandirma, 10200, Turkey. Tel: 90-266-717-0117. E-mail: cbasarir@bandirma.edu.tr
}

Received: August 30, 2016

Accepted: September 29, 2016

Online Published: October 25, 2016

doi:10.5539/ijef.v8n11p48

URL: http://dx.doi.org/10.5539/ijef.v8n11p48

\begin{abstract}
In this study, the effect of raw oil prices and exchange rates on current account deficit of the Turkish Economy has been examined by investigating the short and long run relationship between the current account deficit of the Turkish Economy, raw oil prices (Brent oil prices) and exchange rates (USD/TRY). The Monthly Data between December 1991 and January 2016 were used in the study. The relationships between the variables were tested with the VAR (Vector Auto Regressive) Model. None of the series was found stable after the unit root tests, but it was observed that all the variables became stable when their first differences were taken. Firstly, an unrestricted VAR model was built to determine the long term relationship between the variables. After the long term relationship was found between the variables, the VECM (Vector Error Correction) Model was estimated in order to determine the short term relationship. A mutual granger causality relationship is detected between crude oil prices and current account deficit variables. No causality relationship is found between the other variables.
\end{abstract}

Keywords: current account deficit, exchange rates, oil prices, VAR, Granger causality

\section{Introduction}

In order to sustain the growth in the economy of a country, it is necessary to ensure the energy supply safety, which is the basic input. The fact that current account deficit is one of the basic macroeconomic fragilities of the economy in countries like Turkey increases the importance of the studies conducted and to be conducted on this topic covering the past 2 year-period when the energy prices went down.

In 1973, when the OPEC crisis happened, the USA, which was in the position of being the biggest economy of the world, covered $20 \%$ of total oil production, and covered $12 \%$ of its own oil demand by importing. It is observed that oil ranks first in the order of using the energy sources in the world (40\%). The other energy sources following oil are coal (25\%), natural gas (20\%) and nuclear energy (7\%) (Gürbüz, 2003, pp. 133-134). It has been observed that the dependency on oil has increased in the past century, and a serious part of this demand with $2 / 5$ belongs to the USA. It has also been observed that other developed economies in the world like European Union and Japan follow the USA. In addition, China, which is another fast-growing giant economy today, also needs oil at a great scale. Today, the dependency on oil has decreased with the inclusion of alternative renewable energy sources, and it is aimed that the use of energy sources, which have environmental costs, like oil and coal, is decreased.

There are studies conducted all over the world in order to increase the oil supply and to determine alternative sources. However, the uncertainties in the future growth targets of Canada in producing sand oil, the transition of the oil production activities of the USA to areas other than North America, the studies to develop the deep water areas of Brazil, and the sanctions applied to Russia especially by the European Union are important problems in this context. In addition, the Middle Eastern Region where the majority of the oil reserves of the world exist, mainly Iraq, having an ongoing war creates serious concerns about the safety of oil supply (IEA, 2014, p. 2).

While there is the situation in which the majority of the oil exists in Middle East and the price of oil is determined by a union to which the countries of the region are members, the region is in the position of being the most unstable region in the world. Turkey is located nearby this problematic geographical area, and this causes very serious problems for Turkey both in terms of military, strategic and economic factors. The countries in the 
region are important export markets for Turkey; and on the other hand, these countries are among important energy supply points, which increases the size of the problem twice for Turkey.

Oil is one of the most important energy sources for Turkey as well as for the world, and the rating in the world among the primary energy consumption as of 2014 is as follows; oil 32.6\%; natural gas 23.7\%; coal 30\%; nuclear energy $4,5 \%$; hydroelectric $6.8 \%$; and renewable energy $2.4 \%$. In Turkey this rating is as follows; natural gas $34.9 \%$; petrol $26.9 \%$; coal $28.7 \%$; hydroelectric $7.2 \%$ and renewable energy $2.3 \%$ (Turkish Petroleum Co., 2016).

In the study, short term and long term relations between monthly current deficit numbers for 1996-2016 period and the Brent oil prices and Dollar Exchange Rates will be investigated in Turkey scale. In the study conducted for this purpose, firstly, a literature scan has been conducted to examine the studies in which the relations between current account deficit, exchange rates and oil prices are investigated. Then, the latest developments in the recent period in the economy of Turkey have been investigated, and empirical examinations have been started, and the models formed for the variables are explained. In the last part of the study, the results obtained are evaluated, and a general conclusion is made.

\section{The Developments in the Economy of Turkey in the Last Period}

The influence of the global crisis, which happened as of mid-2007 especially in the USA because the sub-prime mortgaged credits were not paid back, started to influence Turkey as of the late quarter of 2008. As of this period, it is observed that the economy of Turkey went recession, and the growth in GDP was stable at $0.7 \%$ (Şahin, 2016, p. 275). The downsizing was $4.8 \%$ in Turkey in 2009, and there was a growth at a great scale in 2010 in countries which had downsizing in 2009; however, the base effect also played a role in this growth. The economy of Turkey was released from the contractionary effects of the crisis on the GDP in 2010 and 2011 and grew at a rate of $9.2 \%$ and $8.8 \%$, respectively (TOBB, 2014, p. 24).

On the other hand, as of mid-2011, the Euro Crisis started to influence Turkey. In 2011-2013 periods, the world conjuncture was influenced by the European debt crisis, and the capital input slowed down, and therefore, together with the developments in domestic markets, the GNP growth regressed to half of the long-term average growth rate. This rate even regressed to $2.1 \%$ with the influence of this process and the growth investment expenses in 2012 together with the shrinkage in special consumption expenses. In 2013, the GDP grew at a rate of $4.2 \%$, and especially the increase in the public expenses and the domestic demand that was enhanced with the special consumption expenses were influential in this growth (TSI; Turkish Statistical Institute, 2015).

The growth rate in 2014 was limited with $2.9 \%$. In 2015, on the other hand, the growth rate was $4 \%$, and doubled the average growth rate of $28 \mathrm{EU}$ member countries, which was $1.9 \%$. In addition, it is possible to claim that this growth stemmed from the fact that, despite the negative influences of the events in the countries around Turkey, and the failure in the expected enhancing in the Euro region, there was an increase in the extraneous demands (TOBB, 2014, pp. 24-25).

In $27^{\text {th }}$ phase, which covers the most important stages in the import of Turkey because of covering the energy import issue-, the high-rate increase in this issue in recent period attracts attention, which is given in the table below. The "mineral fuels, oils, and the products obtained by distilling these, mineral ozocerites", which are included in this phase, decreased to 34 billion 835 million Dollars with a decrease of $31 \%$ in January-November period of 2015, and this amount was 50 billion 477 million Dollars in the same period in 2014.

The most important role in the decrease in import generally causes a decrease in the commodity prices in the world, and the high-rate decreases in the oil prices play important roles in specific terms. In the period in question, the Barrel of Brent-type crude oil, which progressed over 110 dollars in average in mid-2014, decreased to below 30 dollars in early 2016 with a constant decrease, which was never experienced before in the last 14 years. It is possible to claim that this decrease stemmed from more price activities without any regression in terms of foreign trade indices.

When the reflections of this situation to the economy of Turkey are considered, it is observed that Turkey paid money less than previous years at a rate of $31 \%$; in other words, 15,6 billion dollars less for energy import in the first 11 months of 2015 (especially crude oil, and natural gas indexed to oil prices in the second row). In this way, the Current Account Deficit, which is one of the most important fragilities of the economy in Turkey, becomes narrower.

As it is observed in Table 1 below, there are positive developments in Foreign Trade Balance depending on the decrease in the energy costs especially in the last 2 years' period. 
Table 1. The development of foreign trade in Turkey and the share of energy

\begin{tabular}{lccccc}
\hline & \multicolumn{2}{c}{ Annual (Billion \$) } & \multicolumn{2}{c}{ Regional (Billion \$) } & Change (\%) \\
\cline { 2 - 6 } & 2013 & 2014 & 2014 (January-October) & 2015 (January-October) & $2014-2015$ \\
\hline Export & 151.8 & 157.6 & 131.3 & 120.5 & -8.2 \\
Energy Export & 6.7 & 6.1 & 5.1 & 3.8 & -26.5 \\
Import & 251.7 & 242.2 & 199.0 & 173.2 & -13.0 \\
Energy Import & 55.9 & 54.9 & 46.1 & 32.2 & -30.1 \\
Foreign Trade Volume & 403.5 & 399.8 & 330.3 & 293.7 & -11.1 \\
Foreign Trade Balance & -99.9 & -84.6 & -67.7 & -52.7 & -22.2 \\
Non-Energy Balance & -50.7 & -35.8 & -26.8 & -24.3 & -9.4 \\
Export/Import & 60.3 & 65.1 & 66.0 & 69.6 & 5.5 \\
\hline
\end{tabular}

Source: Republic of Turkey Ministry of Development (2015). Medium-Term Programme 2016-2018.

While the regression in energy prices made the situation of OPEC member countries, mainly Russia, where energy courses have great shares in the export, become difficult; it influenced the economies of countries that were dependent on natural gas and oil, like Turkey, in a positive manner. Turkey is experiencing the comfort of the decreases in energy prices in a medium where foreign currencies are increasing.

When Table 1 and Table 2 are examined it is observed that the export of Turkey has increased at a rate of 157, 6 billion \$ despite the economic and political problems in our commercial partners and the failure of the expected growth in global economy, and has led to the limitation of the rate of the increase in the demands in Euro Region.

The import in 2014 regressed at a rate of $3.8 \%$ and was realized as 242.2 billion dollars. It is possible to claim that the decrease in oil prices and the normalization in gold import are influential in this regression. Depending on all these developments, the Current Account Deficit/GDP rate regressed to 5.8\% in 2014 from $7.9 \%$ in the previous year, and this rate decreased to 5,3\% when gold is excluded (OVP 2016-2018).

By 2015, the ongoing and slow uncertainty in the recovery in Euro Zone and at global level, political and economic developments in the geographical area nearby, the downwards movement in Euro/Dollar parity, and the decrease in oil prices created an income influence on our trade partners, and the export regressed to 143,9 billion $\$$ in this year. When the import for the same period is considered, it is observed that the import level regressed to 207,1 billion \$ showing an inclination to decrease when compared with the previous year due to the ongoing mild process in economic activities, and the developments in foreign Exchange Rates, and the regression in energy and commodity prices in 2015 when compared with the previous year (Medium Term Program 2016-2018). Depending on these developments, the Current Account Deficit was realized as 32,2 billion \$ in 2015 (CBRT, February, 2016).

When the Medium Term Program is considered, it is estimated that the Export will increase at an annual rate of 12.7\%; and Import at a rate of 11,8\% in the program period (2016-2018). In 2016,on the other hand, the export, which is expected to be 155,5 billion $\$$, will reach 201,4 billion $\$$ at the end of the period; and the import, which is expected to be 210,7 billion $\$$ in 2016 , will reach 273,2 billion $\$$ at the end of the period. With the influence of the policy priorities in the abovementioned period such as increasing the export of commodities and services with high added value, and decreasing the dependency of the export and domestic manufacturing on import, it is aimed that the Current Account Deficit/GDP rate will be 3,9\% in 2016; and this rate will regress to 3,5\% at the end of this period.

With the assumption in the program targets that the oil prices will protect their inclination to decrease -although in a limited rate- in 2016, and depending on the developments in Exchange Rates, it is expected that the energy import will be 33 billion $\$$ in 2016 . It is also observed in the following table that the energy import rate will rise to 51,6 billion \$ level with the influence of the predicted growth and oil prices (OVP 2016-2018).

Table 2. Foreign trade realization and expectations in Turkey

\begin{tabular}{lccccc}
\hline & 2014 & 2015 & 2016 & 2017 & 2018 \\
\hline Export (FOB-billion \$) & 157,6 & 143,9 & 155,5 & 175,8 & 201,4 \\
Import (CIF- billion \$) & 242,2 & 207,1 & 210,7 & 243,1 & 273,2 \\
Crude Oil Prices (Brent Dollar/Barrel) & 97,5 & 52,5 & 39,7 & 46,8 & 51,4 \\
Energy Import (billion \$) & 54,9 & 37,8 & 33,0 & 43,7 & 51,6 \\
\hline
\end{tabular}




\begin{tabular}{lccccc}
\hline Foreign Trade Balance (billion \$) & $-84,6$ & $-63,1$ & $-55,2$ & $-67,2$ & $-71,8$ \\
$(\%)$ & 65,1 & 69,5 & 73,8 & 72,3 & 73,7 \\
Foreign Trade Volume/GDP (\%) & 50,0 & 48,6 & 49,8 & 52,6 \\
Travel Incomes (billion \$) & 29,6 & 27,0 & 27,0 & 29,4 & 55,5 \\
Current Account Balance (billion \$) & $-46,5$ & $-31,7$ & $-28,6$ & $-29,3$ \\
Current Account Balance/GDP (\%) & $-5,8$ & $-4,4$ & $-3,9$ & $-3,7$ & $-3,8$ \\
Current Account Balance Except Gold/GDP (\%) & $-5,3$ & $-5,0$ & $-3,8$ & $-3,6$ \\
\hline
\end{tabular}

Source: Republic of Turkey Ministry of Development (2015). Medium-Term Programme 2016-2018.

Note. The figures of 2016-2018 are the estimations of the Ministry of Development.

\section{Literature Review}

There are many studies in the literature conducted on the influences of oil prices on economy. If we classify these studies in certain groups, we can see that the majority of these studies have focused on the influences of oil prices on the increase in prices, and on economic growth (Berument \& Tasci, 2002; Celik \& Akgul, 2011; Oksuzler \& Ipek, 2011; Aydin \& Acar, 2011; Yaylali \& Lebe, 2012; Catik \& Karacuka, 2012; Catik \& Onder, 2013; Gokce, 2013; Yalcin et al., 2014). The issue of whether the increase in energy prices created inflationist influences or not has been investigated in these studies; and also, the influences of this situation on economic growth has been examined; and it has been concluded that generally the increase in energy prices has imitating influences on growth and increased the inflation in countries that imported energy.

In another study conducted by Afsar (2006), it was concluded that the effect of oil prices on Current Account Balance increased even more in situations where there was higher growth rates. It was reported that the additional costs stemming from oil import depending on the increase in oil prices were influential in current account deficit. It is expected that the effect of oil prices on Current Account Balance will be more in developing countries like Turkey when the fact that these countries set more growth targets when compared with the developed countries is considered.

On the other hand, it is observed that there are similar findings claiming that there is a relation in the same direction between the oil prices and external deficit reported in limited number of studies in which foreign balance and net sizes like Current Account Deficit or Foreign Trade Balance are investigated (WB, 2014; Baffes et al., 2015).

Altintas (2013), who conducted a study and investigated the relation between Foreign Trade and oil prices in 1987-2010 periods, concluded that a $1 \%$ increase in real oil prices would increase export at a rate of $0,2 \%$. In another study that covered 1970-2010 periods, it was reported in multiple analyses that there was a positive correlation between the oil prices and the real export rates of Turkey (Rasmussen \& Roitman, 2011). In another study that was conducted in recent period, it has been revealed that the change in energy prices do not have a significant influence on the world foreign demand. In this context, the present studies do not vary according to the countries that export/import oil and focus on total influences (CBRT, 2015).

In another study conducted by Culha et al. (2015), the influence of the serious decrease observed in oil prices on commodity export rates of Turkey has been analyzed and 3 findings have been revealed. The first one is the fact that the negative influence of the decrease in oil prices on the growth of the country group that export oil is higher than the positive influence of it on countries that import oil. The second finding is the income flexibility of the export of Turkey to countries that export oil is extremely lower than the income flexibility of the countries that import oil. The last finding of the study shows that the net influence of the changes in oil prices on the export rates of Turkey is limited when the shares of the country groups in our export are considered.

It is possible to mention 3 basic references when the literature is investigated in terms of the competency of international reserves in covering the import of a country (Cinel, 2015, p. 134). The first one is the fact that the reserves cover $35 \%$ of the annual import rates, which means international reserves, must be at a level that may cover the import of a country for 4,2 months (Triffin, 1960). The second criterion claims that international reserves must cover the amount of import for nearly 4-6 months when the reserves cover the import at a rate of $30 \%-50 \%$ (Williamson, 1973). The last criterion is the comparison of the reserve and the import for 3 months; and according to the criterion, which is still used by IMF to determine the international reserve competency of countries; it is adequate if the reserve level covers 25\% of the annual import rate (Movchan, 2002, p. 4; Wijnholds \& Kapteyn, 2001).

Wijnbergen (1987) conducted a study in which he used different policy tools under public budget limitations, 
and reported that fluctuating exchange rate, external shocks or domestic structural reforms were influential on public budget, and this situation had a "flipping effect" on the inflation and on the exchange rates.

The values of the reserves -as monthly import show- how many months a country is capable of covering import in case it cannot receive any foreign currency. Although the generally accepted rule is "three months", the reserves of many developing countries have reached to a level that may cover the import for durations that are much longer than 3 months. Another definition claims that the rate of the reserves to the commodities imported and to the service expenses shows how long a country can cover the inputs that are needed from the foreign markets by using only the existing financial sources.

\section{Methodology}

In this part of the study, the variables used in the study are given, and information on the method and on the results of the study is provided.

\subsection{The Dataset and the Variables}

In this study, the relation between the Current Account Deficit and Crude Oil Prices and foreign exchange rates has been determined by using the VAR (Vector Auto Regressive) Model. For this purpose, a detailed literature scan was made, and it has been determined that the Current Deficits sensitive to the changes in oil prices and exchange rates. The monthly data of the variables given in Table 3 below have been used in order to determine this situation. The study covers the monthly data between December 1991 and January 2016 period. The dataset used in the study and the explanations of it are provided in Table 3.

Table 3. The dataset used in the model

\begin{tabular}{lcl}
\hline \multicolumn{1}{c}{ Variable } & Definition & \multicolumn{1}{c}{ Explanation } \\
\hline \multirow{2}{*}{ Deficit } & Current Account & The current accounts deficit in Balance of Payments has been used in a manner based on \\
& Deficit & million dollars in a monthly basis. \\
Brent & Oil Prices & It is the barrel price of Brent oil expressed in US Dollars. \\
USD & Dollar Index & The use of Exchange Rate of the Dollar (Major Currencies Dollar Index) as benefit data. \\
\hline
\end{tabular}

Source: Compiled by the Author. Current Account Deficit of Turkey and Dollar Index taken from the Central Bank Of Turkey, Brent oil prices data taken from the web site of Energy Information Administration (www.eia.gov).

\subsection{The Model and the Empirical Results}

The model, which has been established for the purpose of measuring the relations between the variables, has been explained in this part.

\subsubsection{The Model}

There are a great number of time series analyses that may be used in determining the relations between macroeconomic variables. However, since the basic aim in this study is to measure the internal consistency between the variables and since no distinction may be made between variables as independent and dependent, classical time series analyses cannot be used. For this purpose, the VAR (Vector Auto Regressive) Model has been predicted in the study.

An unlimited VAR Model is a method that brings no limitations to the structural model, reveal the dynamic relations between the variables, and explains the macroeconomic relations between the time series and future predictions (Brooks, 2008, p. 290).

A standard VAR model may be expressed as follows;

$$
\begin{aligned}
& Y_{t}=\alpha_{10}+\alpha_{11} y_{t-1}+\alpha_{12} x_{t-1}+\mu_{1 t} \\
& X_{t}=\alpha_{20}+\alpha_{21} y_{t-1}+\alpha_{22} x_{t-1}+\mu_{2 t}
\end{aligned}
$$

When the disruptive error terms in the equation have the property of being White Noise, the disruptive terms in the Standard Model has zero average and stable variance (Kutlar, 2005, pp. 334-335).

In time series that follow a random process, it is extremely important whether the series is stable or not. The series must be defined as stable or non-stable prior to the prediction of the VAR Model.

The graphics of the variables used in the study are given in Figure 1.

When Figure 1 is examined it is observed that the levels of the series are not stable. When the levels of the series are not stable, the probability of facing Fake Regression Problem will increase in studies that will be conducted 
with non-stable series. The variances and co variances of the series will not overlap within the study period, and the predictions will produce fake results. After the levels of the series are determined as not being stable with the graphics, it is necessary to apply the Unit Root Tests in order to determine at which level the series is stable.
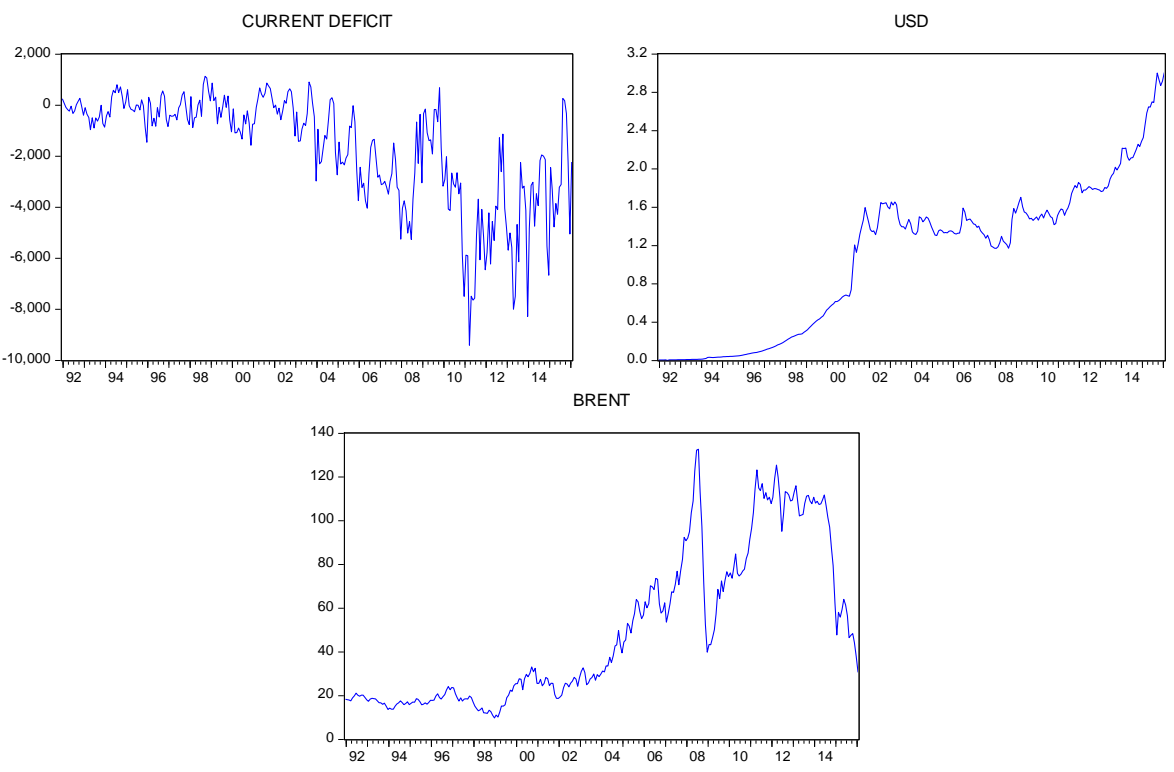

Figure 1. The time series graphics of the variables

\subsubsection{The Unit Root Tests}

If the arithmetic average of a series in time and its variance are stable, and if it does not show a systematic change; or, if the series does not include periodical fluctuations, this type of time series is called as Stable Time Series (Isik et al., 2004). The time series' being stable is an important condition for the predictions towards the future. Because, when analyses are made with non-stable time series, the problem of Fake Regression may appear, and this will make a set of series seem as if it has a relation with another set of series (Ozata\& Esen, 2010). The testing of the variables in terms of being stable has been made with the Unit Root Test. The Enhanced Dickey-Fuller (ADF) and Phillips-Perron (PP) Tests have been used in the study as Unit Root Tests. The Unit Root Test results of the series are given in Table 2.

Table 4. Unit root test results

\begin{tabular}{ccccc}
\hline & \multicolumn{2}{c}{ ADF } & PP \\
\cline { 2 - 5 } Variables & Stable & Stable and Trend & Stable & Stable and Trend \\
\hline Current Account Deficit & $-2.23[0.1932]$ & $-3.006[0.1322]$ & $-2.17[0.2142]$ & $-3,20[0.1114]$ \\
Brent & $-1.79[0.3818]$ & $-2.12[0.5294]$ & $-1.61[0.4727]$ & $-1.73[0.7347]$ \\
Foreign Exchange Rate & $0.77[0.9936]$ & $-1.33[0.8776]$ & $0.97[0.9963]$ & $-1.15[0.9173]$ \\
First Differences & & & & \\
$\Delta$ Current & $-4.79[0.0001]$ & $-4.78[0.0006]$ & $-40.21[0.0001]$ & $-40.10[0.0006]$ \\
$\Delta$ Brent & $-11.23[0.0000]$ & $-11.25[0.0000]$ & $-11.28[0.0000]$ & $-11.29[0.0000]$ \\
$\Delta$ Currency & $-8.54[0.0000]$ & $-8.65[0.0000]$ & $-11.70[0.0000]$ & $-11.76[0.0000]$ \\
\hline
\end{tabular}

When Table 4 is examined it is observed that all variables were not stable according to the ADF and PP Unit Root Test Results. When the first differences were taken, it was observed that they became stable. For this reason, the sets of series were used by taking their first differences.

\subsubsection{The CointegrationTest}

After it was determined that the variables used in the study were integrated at First Degree I (1), the cointegration Analyses must be made in order to determine the long-term relations of the variables. In order to determine whether there is a long-term relation between the series, the Johansen Analysis, which was developed 
by Johansen (1988), was used. Two different methods called as the Maximum Eigenvalue Test and the Path Testing have been made use of in the method developed by Johansen. It is possible to claim whether there are any long-term relations after the results obtained from the tests are compared with critical values (Ozata \& Esen, 2010).

Before Johansen Cointegration Test was applied, an unlimited VAR Model was predicted for the series, and the number of the delays was determined. By considering the number of the delays for the predicted VAR Model, the Sequential Modified LR Test Statistic (LR), Final Prediction Error (FPE), Akaike (AIC) and Hannan-Quinn (HQ) Data Criteria were used.

In case the four criteria gave minimum value in the same delay, it was decided that the optimal lag length of the analysis was 2 .

The length of the determined delay, and the Johansen Cointegration Test Results, Trace Test and Maximum Eigenvalue Test Results are given in Table 3 and Table 4.

Table 5. Johansen cointegration test results

\begin{tabular}{|c|c|c|c|c|c|c|}
\hline The Number of the Cointegration & & & & Maximum & & \\
\hline Equations (Assumed) & Trace Statistics & Critical Value & Probability & Eigenvalue Statistics & Critical Value & Probability \\
\hline Null $(r=0)$ & $52.70783 *$ & 29.79707 & 0.0000 & $48.76776^{*}$ & 21.13162 & 0.0000 \\
\hline Maximum $1(r \leq 1)$ & 3.940070 & 15.49471 & 0.9083 & 3.515711 & 14.26460 & 0.9066 \\
\hline Maximum $2(r \leq 2)$ & 0.424359 & 3.841466 & 0.5148 & 0.424359 & 3.841466 & 0.5148 \\
\hline
\end{tabular}

* Indicates that the $H_{0}$ hypothesis is rejected at $5 \%$ significance level.

When Table 5 is examined it is observed that the maximum eigenvalue statistics and the path statistics results are less than the critical value; and therefore, the hypothesis, which was established as " $H_{0}$ : There is no cointegration", was rejected; and it is concluded that there is at least one cointegrated vector among the variables. Since the calculated test statistics are less than the critical value, the hypothesis claiming that $r \leq 1$ and $\mathrm{r} \leq 2$ has not been rejected. As a conclusion, it is observed that there is a balance between the Current Account Deficit, USD Dollar Exchange Rate and Brent Oil Prices in the long term in the mentioned period for the variables in question.

\subsubsection{The Granger Causality Test}

According to Engle and Granger (1987), if there is at least one cointegrated vector among the variables, it will be more proper to perform a prediction based on VECM Model instead of the VAR Model for the prediction to detect the causality. It has been claimed that the deviations that may occur in the long run might be corrected with a prediction that is based on error correction model.

When a prediction is made with the Error Correction Model, the deviations in the cointegrating regression are shown with Error Correction Term (ECT), which is not included in the VAR Model but included in the VECM Model (Kozhan, 2010, pp. 105-106). One of the basic advantages of the Error Correction Model is allowing using the short-term and long-term information in the series. Another advantage is allowing the avoidance of spurious regression that might appear between the dependent and independent variables (Sevuktekin \& Nargelecekenler, 2010).

The equations of the Error Correction Term that will be predicted in this direction are as follows:

$$
\begin{gathered}
\Delta Y_{1 t}=\alpha_{0}+\sum_{J=1}^{k} \alpha_{1 j} \Delta Y_{1 t-j}+\sum_{J=1}^{k} \alpha_{2 j} \Delta Y_{2 t-j}+\lambda_{1} E C T_{t-1}+\varepsilon_{1 t} \\
\Delta Y_{2 t}=\beta_{0}+\sum_{J=1}^{k} \beta_{1 j} \Delta Y_{1 t-j}+\sum_{J=1}^{k} \beta_{2 j} \Delta Y_{2 t-j}+\lambda_{2} E C T_{t-1}+\varepsilon_{2 t}
\end{gathered}
$$

The $E C T_{t-1}$ in equations (3) and (4) are the delayed value of the Error Correction Term. $\lambda_{1}$ and $\lambda_{2}$, which are the coefficients of the Error Correction Term show the return speed of the $X$ and $Y$ to balance relation. When there is a cointegration, the Granger Causality Tests are made by testing whether the $a_{l j}$ coefficients in Equation (1), and the $\beta_{l j}$ coefficients in Equation (2) are meaningful as groups; and by testing whether the $\lambda_{1}$ and $\lambda_{2}$, which are the coefficients of the Standard F-Test and Error Correction Terms, are meaningful or not (Özata \& Esen, 2010). 
Table 6 . Results of causality test conducted by using VECM

\begin{tabular}{lcc}
\hline & \multicolumn{2}{c}{$\mathrm{m}=2$} \\
\cline { 2 - 3 } Hypotheses & Test Statistics & $\mathrm{p}$ Value \\
\hline $\mathrm{H}_{0}$ : Crude Oil Prices are not the reason of Current Deficit in Granger Terms & 21.87940 & $\mathbf{0 . 0 0 0 0}$ \\
$\mathrm{H}_{0}$ : Exchange Rates (USD) are not the reason of Current Deficit in Granger Terms. & 1.440508 & 0.4866 \\
$\mathrm{H}_{0}$ : Current Account Deficit is not the reason of Crude Oil Prices in Granger Terms. & 11.22929 & $\mathbf{0 . 0 0 3 6}$ \\
$\mathrm{H}_{0}$ : Exchange Rates are not the reason of Crude Oil Prices in Granger Terms. & 0.462074 & 0.7937 \\
$\mathrm{H}_{0}$ : Current Account Deficit is not the Reason of Exchange Rates (USD) in Granger Terms. & 3.356975 & 0.1867 \\
$\mathrm{H}_{0}$ : Crude Oil Prices are not the Reason of Exchange Rates (USD) in Granger Terms. & 2.809874 & 0.2454 \\
\hline
\end{tabular}

The results of the Granger Causality Test, which was conducted to determine the short-term relation between the variables as based on the VECM Model, are given in Table 6 above. According to the causality results, A mutual relationship between current account deficit and crude oil prices was determined between the variables at $1 \%$ significance level in Granger terms. But there isn't any granger relations between the other variables.

In the further parts of the study, the Impulse-Response graphics of the variables will be examined, and their status against each other will be determined.

\subsubsection{Impulse Response Analyses}

The Impulse-Response Analysis is a technique established on structural shocks. If an X variable is not the reason of a $\mathrm{Y}$ variable, a standard deviation shock that will be applied on $\mathrm{X}$ will not have any influences on $\mathrm{Y}$.

When the Impulse Response graphics are examined it is observed that Brent Oil reacted with decrease for nearly 8 periods in return for a 1 Standard Deviation Shock applied to the Current Account Deficit, and then the effect of the shock disappeared. The Dollar Foreign Exchange Rate, on the other hand, reacted to a shock with 1 Standard Deviation applied on the current deficit with an increase for 2 periods with a decrease for 4 periods; and then with a slighter increase for another 4 periods, and the effect of the shock disappeared after the $10^{\text {th }}$ period

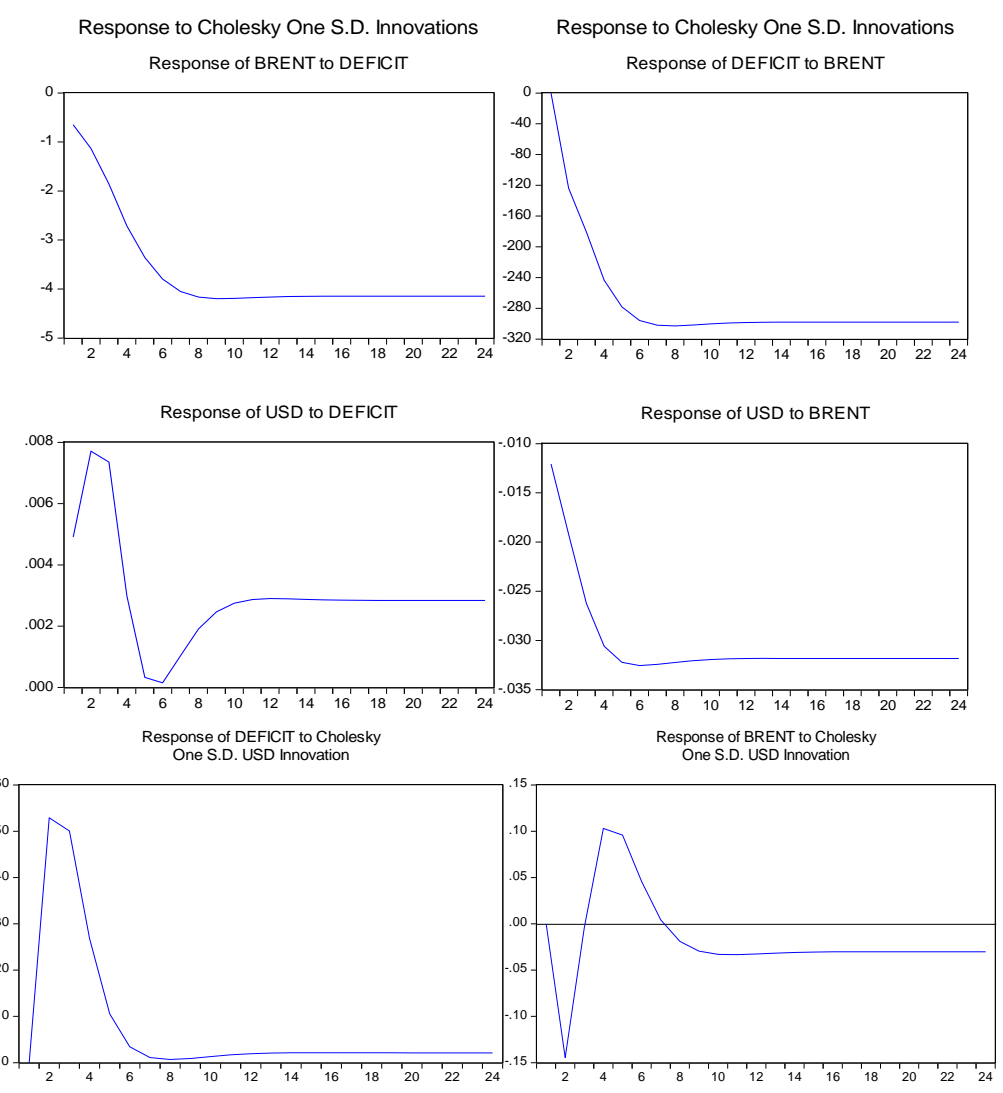

Figure 2. Impulse response graphics 
The reactions of the Current Deficit and Dollar in return for a shock with 1 Standard Deviation applied on the Brent Oil are almost the same. The effect of the shock disappeared after a nearly 5-period decrease.

The Current Account Deficit reacted to 1 Standard Deviation shock applied on the Foreign Exchange Rate with a fast increase that lasted for 4 periods; however, it reacted with a fast decrease for nearly 3 periods, and then the effect of the shock given disappeared after $8^{\text {th }}$ period. Brent oil, on the other hand, firstly reacted with a fast decrease to the shock applied to the Dollar for 2 periods, which is contrary to the situation in current deficit, and then showed a fast increase for 3 periods, and then reacted with a decrease between the $5^{\text {th }}$ and $10^{\text {th }}$ periods, and the effects of the shock disappeared after the $10^{\text {th }}$ period.

\subsubsection{The Variance Decomposition Result}

Variance Separation expresses how much of a change in each variable stems from itself and how much of it stems from the other variables in percentages. Since the effects are shown as percentages, the total of the effects reach a value of 100 (Öztürk, 2008).

In this part of the study, the Variance Separation results of the variables are given, and how much of the prediction error variance is determined by the variables and how much of it is determined by the other variables will be given.

Table 7. The results of the current account deficit variance decomposition

\begin{tabular}{cccc}
\hline Period & Current Account Deficit & Brent & USD \\
\hline 1 & 100 & 0 & 0 \\
6 & 86.25782 & 13.43853 & 0.303648 \\
12 & 70.92993 & 28.85199 & 0.218072 \\
24 & 57.59291 & 42.26746 & 0.139636 \\
\hline
\end{tabular}

When Table 7 is examined it is observed that $57,59 \%$ of the Prediction Error Variance of the Current Deficit is determined by itself, and $42,26 \%$ is determined by the Crude Oil Prices. The effect of the Exchange Rates has been extremely limited in the Prediction Error Variance.

Table 8. The results of the oil price variance decomposition

\begin{tabular}{cccc}
\hline Period & Current Account Deficit & Brent & USD \\
\hline 1 & 2.154219 & 97.84578 & 0 \\
6 & 15.90993 & 84.07226 & 0.017804 \\
12 & 26.21617 & 73.77509 & 0.008737 \\
24 & 30.53864 & 69.45624 & 0.005120 \\
\hline
\end{tabular}

The Variance Decomposition Results of the Crude Oil Prices are given in Table 8. It is observed that nearly 30.53\% of the Oil Prices is explained by Current Account Deficit, and the USD currency has nearly no effects.

Table 9. The results of the USD exchange rates variance decomposition

\begin{tabular}{cccc}
\hline Period & Current Account Deficit & Brent & USD \\
\hline 1 & 1.142631 & 6.899052 & 91.95832 \\
6 & 0.700988 & 20.24179 & 79.05722 \\
12 & 0.424600 & 24.31228 & 75.26312 \\
24 & 0.322779 & 26.09849 & 73.57873 \\
\hline
\end{tabular}

The Variance Decomposition Result of the Foreign Exchange Rate Variable is given in Table 9. When the results are examined it is observed that $26.09 \%$ of the Prediction Error Variance of the USD Foreign Exchange Rate is explained by the Crude Oil Prices and the remaining part is explained by itself.

When the Variance Decomposition Results are assessed as a whole, it is observed that the variables do not have much interaction in the short-term with each other for the period in question; and in the long-run, especially the Current Account Deficit Variable and the Crude Oil Prices are influential in explaining their prediction error 
variances. The Causality Results in Granger, which was conducted before, and the cointegration Analysis Results confirm each other.

\section{The Results and Evaluations}

The short-term and long-term relation between the Current Account Deficit, which is one of the important problems of developing countries, and the Exchange Rates and Oil Prices, which are in interaction in theory, has been examined by making use of Time Series Analysis Techniques. The VAR Model has been used in the study, and the long-term relation between the variables has been examined with Johansen cointegration analysis. A long-term relation has been determined between the variables. When the fact that the changes in Exchange Rates and Oil Prices are reflected to the Current Deficit with a 2-3 year delay is considered, the result obtained is consistent with the theory.

The short-term relation between the variables has been investigated with the Causality Analysis developed by Granger; A mutual granger causality relationship is detected between crude oil prices and current account deficit variables. No causality relationship is found between the other variables. When Granger Causality test results are evaluated, it is found that crude oil prices and current account deficit affects each other in the short run.

When we look at the Impulse-Response Graphics of the series, it has been observed that the effects of the shocks with 1 Standard Deviation applied on the series disappear in the short-term. When the variance decomposition results are examined it is observed that the Prediction Error Variances of almost all of the series are explained by themselves in the short-term; however, it has also been determined that the rate of being explained by the other variables increase in the long-term.

The normalization of the Current Deficit, which is the most important fragility of the economy of Turkey, is no doubt parallel to the decreasing of the Foreign Trade Deficit to the lowest levels possible. The decreases in the oil prices in recent periods pose an opportunity in this sense for the Economy of Turkey, and it is possible to decrease the Foreign Trade Deficit; and therefore, the Current Accounts Deficit. However, the possibility of the increase in prices is not far. For this reason, it is necessary to convert the present situation into an advantage in export by providing cheap energy; and the opportunity of transferring it into productive investments must be benefited well.

\section{References}

Afşar, B. (2006). Petrol Fiyatlarının Ekonomi Üzerindeki Etkisi. Konya Ticaret Odast- Etüd Araştırma Servisi, 17.

Altıntaş, H. (2013). Türkiye'de Petrol Fiyatları, İhracat ve Reel Döviz Kuru İlişkisi: ARDL Sınır Testi Yaklaşımı ve Dinamik Nedensellik Analizi. Uluslararası Yönetim İktisat ve İşletme Dergisi, 9(19), 1-30. http://dx.doi.org/10.11122/ijmeb.2013.9.19.459

Baffes, J., Kose, M. A., Ohnsorge, F., \& Stocker, M. (2015). The Great Plunge in Oil Prices: Causes, Consequences, and Policy Responses. World Bank Policy Research Note, 15(01). Retriewed from http://www.worldbank.org/content/dam/Worldbank/Research/PRN01_Mar2015_Oil_Prices.pdf

Berument, H., \& Taşçı, H. (2002). Inflationary Effect of Crude Oil Prices in Turkey. Physica A Statistical Mechanics and its Applications, 316(1), 568-580. http://dx.doi.org/10.1016/S0378-4371(02)01025-7

Beyamil, Ö. (2008). Makroekonomik Faktörlerin İstanbul Menkul Kıymetler Borsası Ulusal-100 Endeksi ve Volatilitesi Üzerindeki Etkilerinin İncelenmesi (1997-2006). Unpublished Master Thesis, İstanbul Teknik Üniversitesi.

Brooks, C. (2008). Introductory Econometrics for Finance. Cambridge University Press. http://dx.doi.org/10.1017/CBO9780511841644

Çatık, A. N., \& Karacuka, M. (2012). Oil Pass-Through to Domestic Prices in Turkey: Does the Change in Inflation Regime Matter? Ekonomskaistraživanja, 25(2), 277-296. Retrieved From http://hrcak.srce.hr/file/128941

Çatık, A. N., \& Önder, A. Ö. (2013). An Asymmetric Analysis of The Relationship Between Oil Prices and Output: The Case of Turkey. Economic Modelling, 33(C), 884-892. http://dx.doi.org/10.1016/j.econmod.2013.06.004

Çelik, T., \& Akgül, B. (2011). Changes in Fuel Oil Prices in Turkey: An Estimation of the Inflation Effect Using VAR Analysis. Journal of Economics and Business, 14(2), 11-21. Retrieved From https://www.u-picardie.fr/eastwest/fichiers/art98.pdf 
Cinel, E. A. (2015). Türkiye'de Döviz Rezervleri Yeterli mi? Mehmet Akif Ersoy Üniversitesi SBE Dergisi, 7(12), 131-144. Retrieved from http://dergipark.ulakbim.gov.tr/makusobed/article/view/1098001173/1098000829

Çulha, O. Y., \& Kalafatçılar, M. K. (2014). Türkiye'de İhracatın Gelir ve Fiyat Esnekliklerine Bir Bakış: Bölgesel Farklılıkların Önemi. TCMB Ekonomi Notlarl, 2014-05. Retrieved From http://www.tcmb.gov.tr/wps/wcm/connect/14c45305-24...9b-9cd6-0eafef67e2bd

Çulha, O., Özmen, U., \& Yılmaz, E. (2015). Petrol Fiyatlarının İhracat Üzerindeki Etkisi. TCMB Ekonomi Notlarl, Say1, 2015-10. Retrieved from http://www.tcmb.gov.tr/wps/wcm/connect/deae2ce6-dea3-46b3-9730-e8c22519fc4a/en1510.pdf?MOD=AJ PERES\&CACHEID=ROOTWORKSPACEdeae2ce6-dea3-46b3-9730-e8c22519fc4a

Dünya, B. (2014). Focus Note, Aralı. Dynamics and Control, 12, 231-254. http://dx.doi.org/10.1016/0165-1889(88)90041-3

Engle, R. F., \& Granger, C. W. J. (1987). Cointegration and Error Correction: Representation, Estimation and Testing. Econometrica, 55, 251-276. http://dx.doi.org/10.2307/1913236

Gökçe, A. (2013). The Dynamic Impacts of Oil Price Shocks on Turkey's Economic Growth. Journal of Economics and Sustainable Development, 4(8), 181-192. Retrived from http://www.iiste.org/Journals/index.php/JEDS/article/viewFile/5856/5973

Gürbüz, V. (2003). Petrol, Petrol Politikaları ve Orta Doğu. Avrasya Dosyası Enerji Özel, 9(1). Retrived from http://www.21yyte.org/assets/uploads/files/133-168\%20vedat.pdf

IEA. World Energy Outlook, 2014.

IMF. (2000). The Impact of Higher Oil prices on the Global Economy. Policy Paper, 8th December. Retrieved from http://www.imf.org/external/pubs/ft/oil/2000/

Işık, N., Acar, M., \& Iş̧1k, H. B. (2004). Enflasyon ve Döviz Kuru İlişkisi: Bir Eşbütünleşme Analizi. Süleyman Demirel Üniversitesi İktisadi ve İdari Bilimler Fakültesi Dergisi, 9(2), 325-340. Retrieved from http://dergipark.ulakbim.gov.tr/sduiibfd/article/view/5000122783/5000113088

Johansen, S. (1988). Statistical Analysis of Cointegration Vectors. Journal of Economic. http://dx.doi.org/10.1016/0165-1889(88)90041-3

Kozhan, R. (2010). Financial Econometrics with Eviews.Ventus Pub.

Kutlar, A. (2005). Uygulamalı Ekonometri. Ankara: Nobel Yayın Dağıtım.

Movchan, V. (2002). Criteria for International Reserve Adequacy: What Level of Reserves Does Ukraine Need? Institute for Economic Research and Policy Consulting, Kyiv, 15 August. Retrieved from http://citeseerx.ist.psu.edu/viewdoc/download;jsessionid=D4F05C3DDC71555607EA5DF959D13056?doi= 10.1.1.202.1544\&rep=rep1\&type=pdf

Öksüzler, O., \& İpek, E. (2011). Dünya Petrol Fiyatlarındaki Değişimin Büyüme ve Enflasyon Üzerindeki Etkisi: Türkiye Örneği. Zonguldak Karaelmas University Journal of Social Sciences, 7(14). Retrieved from http://www.arastirmax.com/en/system/files/dergiler/2053/makaleler/7/14/arastirmax-dunya-petrol-fiyatlarin daki-degisimin-buyume-enflasyon-uzerindeki-etkisi-turkiye-ornegi.pdf

Özata, E. (2014). Sustainability of current account deficit with high oil prices: Evidence from Turkey. International Journal of Economic Sciences, 3(2), 71-88. Retrieved from http://www.iises.net/download/Soubory/soubory-puvodni/pp71-88ijoes_V3N2.pdf

Özata, E., \& Esen, E. (2010). Reel Ücretler İle İstihdam Arasındaki İlişkinin Ekonometrik Analizi. Journal of Anadolu University Social Sciences, 10, 55-70. Retrieved from http://w2.anadolu.edu.tr/arastirma/hakemli_dergiler/sosyal_bilimler/pdf/2010-2/2010_02_05.pdf

Özlale, Ü. (2009). Cari açık ve Petrol Fiyatlarının Kısa Dönem Analizi. Seta İktisat Seminerleri Dizisi, Ankara.

Özlale, Ü., \& Pekkurnaz, D. (2010). Oil Prices and Current Account: A structural Analysis for the Turkish Economy. Energy Policy, 38(8), 4489-4496. http://dx.doi.org/10.1016/j.enpol.2010.03.082

Rasmussen, T., \& Roitman, A. (2011). Oil Shocks in a Global Perspective: Are They Really That Bad? IMF Working Papers, 11/194. Retrieved from: https://www.imf.org/external/pubs/ft/wp/2011/wp11194.pdf

Republic of Turkey Ministry of Development. (2015). Medium-Term Programme 2016-2018. Retrieved from http://www.kalkinma.gov.tr/Pages/content.aspx?List=28363ffa-6f2c-4400-86bc-ca5decdb5161\&ID=12\&So urce $=\mathrm{http} \% 3 \mathrm{~A} \% 2 \mathrm{~F} \% 2 \mathrm{Fwww} \% 2$ Ekalkinma\%2Egov\%2Etr\%2FPages\%2FOrtaVadeliProgramlar\%2Easpx\& 
ContentTypeId=0x0100F586C93FC4CA2749A016DD998B6133D2

Şahin, H. (2016). Türkiye Ekonomisi. Ezgi Yayınevi Bursa.

Sevüktekin, M., \& Nargelecekenler, M. (2010). Ekonometrik Zaman Serileri Analizi: Eviews Uygulamall. Ankara, Nobel Press.

TCMB. (2015). Uluslararası Enerji Fiyatlarının Makroekonomik Etkileri. Enflasyon Raporu, 2015.

TOBB. (2014). Ekonomik Rapor 2014.

Triffin, R. (1960). National Central Banking and the International Economy. The Review of Economic Studies, 14(2). Retrieved from http://www.jstor.org/stable/2296086

Wijnbergen, S. (1987). Fiscal Deficit, Exchange Rate Crises and Inflation. NBER Working Paper Series, No: 2130, Washington D.C. Retrieved from http://www.nber.org/papers/w2130.pdf

Wijnholds, J., \& Kapteyn, A. (2001). Reserve Adequacy in Emerging Market Economies. IMF WorkingPaper, No. 143. Retrieved from http://www.imf.org/external/pubs/ft/wp/2001/wp01143.pdf

Williamson, J. (1973). International Liquidity: A Survey. The Economic Journal, 83, 331, 685-746. http://dx.doi.org/10.2307/2230668

\section{Copyrights}

Copyright for this article is retained by the author(s), with first publication rights granted to the journal.

This is an open-access article distributed under the terms and conditions of the Creative Commons Attribution license (http://creativecommons.org/licenses/by/4.0/). 